\title{
KADINLARIN SIYASAL HAK MÜCADELESINDE FARKINDALIK OLUŞTURAN BİR ERKEK DÜŞÜNÜR: JOHN STUART MILL
}

\author{
CREATES AWARENESS IN THE STRUGGLE FOR THE POLITICAL RIGHTS OF \\ WOMEN A MASCULINE DISCOURS: JOHN STUART MILL
}

\author{
Rabia Bahar ÜSTE
}

ÖZ

Kadın ve siyaset, bir o kadar yakın aynı zamanda da tarihsel süreç içerisinde bir o kadar birbirinden uzak kavramlar olarak karşımıza çıkmaktadır. Genel oy hakkının elde edilmesi için verilen mücadelede kadın kadının destekçisi olmasına rağmen erkekler tarafından karar mekanizmalarından uzak tutulmuşlardır. Nedeni ise seçme ve seçilme haklarının olmamasıdır. Çalışma, 19. yüzyıl boyunca genel oy hakkı için mücadele eden kadınların destek görmemeleri üzerine yaşadıkları özgürleşme sorunlarını anlatmaktadır. Aynı zamanda, karar mekanizmalarında erkek egemen söylemi aşamayan kadınların, bu konuda ilk kez bir erkek tarafından savunulmasının nasıl bir çığır açabildiğini imgelemektedir. Kadını ötekileştirmeden savunan bir erkek düşünürün söylemlerinin kadınların oy hakkı konusundaki değeri ele alınacaktır.Bu çalışmada kadınlar, genel oy hakkı için mücadele ederken, bir erkek düşünürün onların yanında yer alarak, bu mücadeleye eşi ile birlikte nasıl destek olduğu ortaya konulmaya çalışılacaktır. Kadınların genel oy hakkı için destek veren ve bu konuda farkındalık oluşturan yö- nüyle John Stuart Mill anlatılacaktır.

Anahtar Kelimeler: Kadın, toplumsal cinsiyet, öteki, temsil, seçim, demokrasi.

\begin{abstract}
Women and politics in the historical process just as much from each other, so close and distant at the same time are concepts. Although a supporter of the strugggle for achieving universal suffrage by men and women in decision-making were excluded. The reason is the lack of suffrage. The study, men with a different perpective to the topic as a result of the gains focuses on supporting women in politics for what could be. Women who cannot overcome male dominant discourse in decision mechanisms, fort he first time on this issue is defended by a man and awarenes of women's issues and politics is a man's rhetoric imagined.
\end{abstract}

Keywords: Women, gender, other, representation, election, democracy.

\section{GİRIŞ}

Siyasal hakların kazanılması kadınların zor ve uzun mücadelelerinin sonucudur. Kıta Avrupası'nda Fransız Devrimi'ne kadar ve İngiltere'de ise devrim sonrasında eşitlik / özgürlük gibi kavramları içeren yasal düzenlemeler ele alınmaya başlanmış olsa da "kadınlar" bu düzenlemelerin içeriğinde yer almamıştır. Aydınlanma felsefesi olarak adlandırılan ve karanlıkların sona erdiği söyleminde iddialı olan bu süreçte özellikle yönetenler ve karar mekanizmalarını oluşturanlar yine erkekler olarak tarih sayfalarındaki yerlerini almışlardır. Yönetenlerin ve karar mekanizmaları içinde kanun yapanların erkekler olması kadınların siyasal alanda bulunma ve siyasal haklarını elde etme konusunda mücadelelerinin gecikmesine neden olmuştur.

a Doç.Dr., Dokuz Eylül Üniversitesi, İzmir Meslek Yüksekokulu, Yerel Yönetimler Programı, rabia.uste@deu.edu.tr, Orcid ID: https://orcid. org/0000-0002-2525-0968 
Kadınların yasalar ve kurumlarla engellenen siyasal hakları aynı zamanda erkeklerle toplum içerisinde rekabet güçlerini azaltmıştır. Bu durumda toplumlarda haksız rekabete uğrayan kimdir? sorusuna yanıt ise öteki olarak kabul gören kadın olarak karşımıza çıkmaktadır. Yüzyıllar boyunca çeşitli toplumlarda öteki olarak kabul gören kadınlar özellikle özgürlük ve eşitlik kavramlarının kendileri için de geçerli olabilmesi adına siyasal alanda yer aramışlardır. Karar mekanizmalarında kadınların yer alabilmesi için tüm karş1 duruşlara rağmen "Avam Kamarası”nda bunu yasa önerisi olarak sunan Mill, kadınlara genel oy hakkı konusunda beklenen etkinin ötesinde bir yararlılık sağlamıştır. Modernleşme kavramının içeriğinin zenginleştirilmeye çalışıldığı süreçte, modern toplumların ikircikli konularının başında kadınların ötekileştirilmesi ve haklarının önüne eşitsizliği belirginleştiren setler çekilmesi gelmektedir. Özellikle kadınların oy hakkı konusunda yaşanılan eşitsiz durum uzun yıllar toplumlarda tartışılan konuların başında yer almıştır. Aydınlanma felsefesi ve sonrasına bakıldığında Mill, birçok düşünürden farklı olarak, kadınların oy hakkı için eşi ile birlikte çaba göstermiştir. Çalışmada, kadınların oy hakkı için mücadele eden ve bu konunun yasalaşması için çaba gösteren yönleriyle "John Stuart Mill” anlatılacaktır.

\section{KADINLARIN ÖZZGÜRLEŞME SORUNSALI}

Avrupa'nın demokratikleşmesi 1815'ten itibaren kıtanın temel süreçlerinden biri ve modern bir Avrupa bilincinin ortaya çıkmasının ana etkeni olmuştur. Bu dönem ile ilgili yapılan araştırmalar demokratikleşmenin sadece kurumları değil toplumu ve "siyaset kültürünü" de etkilediğini ortaya koymaktadır. Bu sürece bağlı olarak gelişen Batı kültüründe, liberal demokrasi üç kavrama dayanmaktadır. Bunlar: (Soutou, 2014, s.404-405): serbest seçimlerle iradesini ortaya koyan halkın tek meşruiyet kaynağı olması, insan hakları ve temel özgürlükler -hukuk devleti-dir. Liberal demokrasinin işlerlik kazanması, insan hakları, özgürlük ve eşitlik gibi kavramların kadın-erkek herkes adına ele alınması gerekliliğini de beraberinde getirmiştir.

Kadınlar 1800'lü yıllarından başından itibaren Doğu ve Batı'da farklı muamelelere maruz kalmışlardır. Kadınların yasal haklarının sorgulanması bu yüzyılın sonlarında ele alınmaya başlanmıştır. Buna rağmen bazı şaşırtıcı örnekler bulmak mümkündür. Örneğin, bir Rus kadının malı evlendikten sonra da onun mülkiyetinde kalırken, İngiltere'de mülkiyet kocaya geçmekteydi. Ayrıca, 18. yüzyılda Fransa' da yaşayan varlıklı kadınların belirli ölçülerde bağımsızlığa sahip olduklarına dair araştırmalar bulunmaktadır (Roberts, 2010, s.310-311). Çeşitli ülkelerde haklar konusunda kadınlara farklı alanların açılması, kadınların insan hakları kavramını ve içeriğini sorgulamasına neden olmuştur.

Aydınlanma söylemi, 18. yüzyıl Batı tarihine tartışmasız bir şekilde damgasını vurmuştur. Batı tarihi, özelde Avrupa ve Britanya tarihinin vazgeçilmez dönüm noktalarından biri olarak görülen Aydınlanma değerlerinin gelişimidir (Gürses, 2005, s.77). Aynı zamanda gelişim kadar sancılı bir dönemi ifade eden Aydınlanma çağı, aynı zamanda haklarını arayan ya da seslerini duyurmaya çalışan kadınları da anlatan bir süreçtir.

Devrimler sonrasında yaşanılan dünyadaki yeni yapılanmalar, kadın bilincinin yükselmesini ve özgürlük alanlarının kendileri için de açılması gerektiğini ortaya koymuştur. Ayrıca kadınlar, cinsiyetin özgürlüklerin elde edilmesinde bir farklılığ 1 ortaya koymaması gerektiğinin altınıçizmişlerdir. Ailede başlaması gereken özgürlük ve eşitlik anlayışının toplumsal yaşamda da ele alınması gerekliliği üzerinde durmuşlar ve cinsiyet ayrımcılığına karşı bir savaşım vereceklerini Fransız, İngiliz ve Amerikan Devrimleri ile bildirmişlerdir. Özellikle kadınlar, oy kullanma hakkında cinsiyet ayrımcılığının kabul edilemeyeceğini yüksek sesle dile getirmişlerdir. Margaret Livingston oy hakkı ile ilgili kadınların devrimlerden sonra bir savaş başlattıklarını şu sözleri ile anlatmıştır “...Kadın erkek ortak yaşanan bir toplumda oy hakkının üstün kabul edilerek erkeklere verilmesi cinsiyetleri ayrıştıran ve toplumların yaşam enerjilerinin düşmesine yol açan bir durumdur... Bu durumun kadın-erkek eşitlenmesi gerekmektedir..." (Kerber, 1980, s.35). Kadın-erkek eşitliği için mücadele eden kadınlar, yüzyıllar boyunca gerekli desteği görememişlerdir. Sosyal alana çıkamayan kadınlar, eşitlik ve özgürlük sorunsalını aşmada çağın düşünürlerinin ortaya koydukları yeniliklerden gerektiği kadar yararlanamamışlardır. Çağın düşünürleri, çok çeşitli konularda yine çağın ilerisinde fikirler üretmiş olmalarına rağmen bunların çoğu erkeklerin yararlandığı alanlar olarak tarihteki yerlerini almışlardır. Bu düşünürlerden bazıları, siyasal hakların kullanılmasında özellikle oy hakkı konusunda kadın ve erkek için düşünceleri bağlamında ele alınmıştır.

Machiavelli, Rönesans dönemi İtalyan yöneticilerin ilkesiz ve acımasız davranışlarını gözlemlemiş ve "Prens" isimli kitabında ahlak ile siyasetin karşılaştırılmamasını tavsiye etmiştir. Sivil toplumun ilkelerini bir siyaset teorisyeni olarak ortaya koymuştur (Robinson ve Groves, 2012, s.50). Dönemin düşünürlerinden Machiavelli'ye göre insan, vefasız, güvenilmez ve bencildir. Yasa koyucular, yasalara itaat edenlerden daha iyi değillerdir. Machiavelli, prensin yönetimde başarılı olacağına inanır. Siyasette kural koyucuların ve uygulayıcıların erkek olması gerektiğini vurgular. Kadınlar için siyasal alanda yeni bir görüş ortaya koymayan düşünür, 
kadınları ev işleri ve çocuk bakımında başarılı kılar (Redhead, 2001, s.103). Yönetimde ve karar alma mekanizmalarında erkeklere yer veren düşünürün kadınların toplumda yaşadığı sorunları görmezden gelmesi, kadınların siyasal alandaki mücadelelerinde ne denli yalnız olduklarına daişaret etmektedir.

Montesquieu, siyasal haklar ve kadınlar konusunda, seçme hakkından yoksun olanları açık bir biçimde ifade etmiş olmasa da, çağının hakim değer yargılarını yansıtan bir şekilde kadınların seçme ve seçilme hakkından yararlanmaması gerektiğini düşünür, hatta onları birer yurttaş olarak bile görmez. Bu değer yargısı bazı cümlelerinde açık ifadesini bulur, "Kadın milletinin bir hayli başarı sağladığı gülünç olma sanatından bir işe yaramayan o zarafet sanatı... Kadınlar zayıf yaratıklardır; kibire değil boş şeylere kaptırırlar kendilerini... Kadınların eve hakim olmaları hem akla hem doğaya aykırıdır" (Zabcı, 2012, s.552) der.

Rousseau'nun, 1762 yılında yazdığ 1 "Toplum Sözleşmesi"nin amacı insanların toplumsal olaylarda erdeme nasıl ulaşabileceğinin ortaya konulması içindir. Toplum Sözleşmesi'nde “İngiltere'nin insanları kendilerini özgür olarak görürler, ama bu tamamen bir yanılsamadır. Sadece parlamento üyelerini seçmede özgürdürler. Hoşa giden anlık özgürlük aslında özgürlüklerini kaybetmelerine yarıyor" ifadesi ile oy hakkının genel olması ile ilgili inancının olmadığını da ortaya koymaktadır (Redhead, 2001, s.174). Oy eşitsizliği yanında, kadınla erkeğin aynı mülkiyet hakkına sahip olamayacağını da vurgular. Rousseau'nun, düşün dünyasında kadınlar ve erkekler eşit değildir. Kadının ilk görevi aileye iyi bakmaktır. Rousseau, "Bir kadında ilk ve beğenilecek yön uysallıktır... Kadın kendisi için uysal olmalıdır... Erkekler, hırçınlık ve inatçılık silahları ile yenilmeyeceklerini bilirler" der (Alkan, 1993, s.68). Rousseau, toplum sözleşmesini yapanların, dolayısıyla yurttaşlık statüsüne kavuşanların yalnızca ergin erkekler olduğunu kabul eder. Bu görüşünün temelinde, eşitlik düşünürü olarak alg1lanan Rousseau'nun paradoksal bir şekilde kadın-erkek eşitsizliğini benimsemesi yatmaktadır. Rousseau, "Emile" deki deyişiyle "... Arzuları ve gereksinimleri bakımından erkeğe bağlı olan kadın, itaat etmek için yaratılmıştır... Öyle ki her kadın bir kocanın adaletsizlikleri ve haksız davranışlarına bile yakınmadan katlanmayı öğrenmelidir küçük yaşta..." (Ağaoğulları, 2012, s.581) der. Düşünür, genel iradeyi halk egemenliği kavramına ön bir hazırlık olarak görür. Burada, siyasal organizmayı oluşturan seçmenleri halk yararına ya da genelin yararına tanımlarken erkek seçmenleri anlatır ve erkeklerin kendi düşüncelerini açıklaması yoluyla toplum tarafindan dinlenmesinin önemi üzerine özgür bireyi erkek özelinde tanımlar (Redhead, 2001, s.174).
Hobbes, siyaset felsefesini anlatabilmek için, "insanlar içgüdüsel olarak bencil ve acımasızlar bu yüzden onları ahlaki bir varlık haline getirmek için yapılacak her girişim zaman kaybıdır” (Robinson ve Groves, 2012, s.51) der. "Leviathan" isimli kitabında insan doğasının karamsar bir açıklamasını yapar. Hobbes, özgürlüğü ve insan açısından özgürlüğ̈̈ “... özgür bir insan gücü ve zekasıyla yapmaya muktedir olduğu şeylerde, istediği şeyleri yapması engellenmemiş olan birisidir" (Kulak, 2013, s.227) ifadesine yer verir. Hobbes, siyasal yaşamı ve devlet anlayışını “....bir insanı ya da insanlardan oluşan bir meclisi atarlar ve varlığı ortaya çıkarırlar; herkes onu genel barış ve güvenliği sağlamakla ilgili konularda hareket eden ya da harekete neden olan bir otorite varlık olarak kabullenir, sahiplenir ve böylece kendi iradelerini onun iradesine, kendi yargılarını onun yargısına teslim ederek boyun eğerler" söyleminde meclis için oy veren ve seçilenlerin sadece erkek olması ile ilgili olumsuzbir tutuma sahip olmamıştır (Redhead, 2001, s.141). Kadınların kamusal alan içinde güçlü erkekler tarafından ezileceğini ve kamusal alana çıkmanın "farklılığa" aynı zamanda "özel eğilime” yol açacağına işaret eder (Çaha, 2010, s.32).

Hegel, uygarlık ve kültür kavramlarını inceyen bir düşünürdür. Avrupa'daki yeni uygarlık kelimesine eski kültür kelimesinin eşlik ettiğini vurgular. 1830 yılında Berlin Üniversite'sinde uygarlık ve kültür kelimelerinin ayrılmaksızın bir arada kullanılması gerekliliğini anlatırken, iki kavramı erkekler üzerinden anlatmıştır. Siyasal kültür açısından kadını görmezden geldiğinin çalışmalarla ortaya konulduğu ifade edilmiştir (Braudel, 2001, s.33). Hegel, aile bütünlügünü sağlayan kadın temasını sık sık tekrar eder. Kadın bilincinin yaşamın duyumsal görünürlülüğü bakımından daha üstündür ve öznel açıdan daha pratiktir ve güvenilirdir, böy- lece toplumun uzak nesnel yasalarından çok aile ve aile bağ- ları kadına daha yakındır (Monk, 2004, s.543). Aile bütünlü- ğünü sağlayan kadın temasını "bütünlüğün kendisi ile özdeş olmadığına kendi kavramı ile inkar ederek bütünlüğe karşı koymak gerekir. Böylece olumsuz diyalektik, kendi çıkış noktasına olduğu kadar özdeşlik felsefesinin en yüksek ka- tegorisine de bağlıdır. $\mathrm{Bu}$ ölçü içerisinde o da yanlış olarak kalır, karşıtı olan düşünülen özdeşlik mantığına katılır" ifa- deleri ile anlatmıştır (Assoun, 2012, s.40). Ona göre kadın- lar, "kamusal alanda farklı istekler taşıyan bu doğrultuda özgürlük peşinde olan özneye dönüşemezler. Kadın doğasını aşarak erkek gibi özgürlük ve akıl yoluyla politik ve tarihsel aktör olma sürecine giremediği için tarihin dışında kalır". Yine Hegel'e göre her yönden kadınlar, tarihin dışında kalmaya devam edeceklerdir (Çaha, 2010, s.40).

Locke sadece liberal düşünce üzerindeki etkisinden dolayı değil, ilgi alanının zenginliğinden dolayı da düşünce tarihinin temel figürlerinden biridir. Locke'dan önce 
İngiltere'de siyasal hareketler, "Kazıcılar" ve "Düzenleyiciler" (Zabcı, 2012, s.476) olmak üzere ikiye ayrılmıştır. Kazıcılar, krala karşı mücadele verenler olarak tarihe geçerken, Düzenleyiciler, kamusal alan ve burada eşit haklara sahip olacakları belirleyenler olarak siyasal haklar için çalışanlardır. Düzenleyiciler, eşit oy hakkından yana olmalarına rağmen kadınları, dilencileri ve hizmetçileri bu hakkın dışında bırakmışlardır. Locke bu dönemi eleştirerek, eşitlik, özgürlük, akılcılık konularında insanların eşitliği üzerinde durmuştur. Ancak, Toplum Sözleşmesi'nde "Uygar yönetime atılan adım" demesine karşın Lock'un sözleşme d1şında bıraktıkları, akıl sağlığı yerinde olmayanlar, köleler, yabancılar ve kadınlardır. Locke, doğa yasasını bilen yeteneğin babadan oğula aktarıldığını söyleyerek kadınları sözleşme dışında bırakmıştır (Zabcı, 2012, s.495). Locke, kamusal alanda kadınların erkeklerle rekabete giremeyeceğini ve yenilmelerinin sürekli olacağını ele almaktadır. Buna ilişkin olarak "kadınların en önemli görevi özel alanda iyi çocuk yetiştirmektir" der. Toplumda kadının kimliği aile içinde formüle edilir (Çaha, 2010, s.31).

Çağın düşünürlerinin ortak teması kadının evi ve çocukları ile ilgilenmesinin kamusal alana çıkmaktan dahaönemli olduğudur. Oysa, siyasi tarihe bakıldığında kadın, kamusal alana çıkmadığı gibi toplumda da kendisini "öteki" olarak nitelendirmektedir.

\section{3. ÖTEKİ OLMAK VE KADIN}

Toplumların uzun yıllar tartıştığı konuların başında öteki olmak ve ötekileştirmenin özellikle kadınlar için oluşturduğu olumsuzluklardır. Herkese saygı, ötekine yani farklı oluşu nedeniyle diğeri olarak kabul edilenlere de saygı gösterilmesi koşuludur. Ötekiyle bizlerden biri olarak dayanışma göstermek de, tözsel (kendi kendine var olan) olarak her şeye direnen ve gözenekli sınırlarını sürekli daha da öteye taşıyan bir topluluğa ait esnek "Biz"i kapsar. Toplumdaki bu ahlaksal yapı, ayrımcılığın ve haksızlığın kaldırılmasıyla birlikte marjinalleri, karşı1ıklı saygı temelinde benimseme üzerine kurulmuştur. Habermas'a göre ötekini benimsemek "kendi içine kapatmak ve ötekine karşı kapanmak demek değildir. Ötekini benimsemek, toplumsal sınırların herkese - hatta ve özellikle de, birbirine yabancı olan ve birbirine karşı yabancı kalmak isteyenlere-açık olması demektir" (Habermas, 2012, s.9). Kadın, aile içinde, sosyal alanda, eğitimde, siyasal ve kültürel boyutta genel olarak ötekileştirilendir.

Tarihte kadın, öteki ve ötekileştirme kavramlarını sosyal alanın değişik yönlerinde yaşamıştır. Örneğin, 18. yüzyılın başlarında İngiliz dergisi olan "Spectator" erkek okuyucularının yanında kadınlara da hitap edilmesi gerektiğini savunarak, kadın haklarının neler olabileceğini tartışmıştır. Kadınların hakları ile ilgili büyük değişikliğe dergi yol açmamış olsa da geleneksel yaşamın içinde kadının yeri ile modernize edilen yaşamda kadının yeri arasındaki farklılıkları ortaya koyarak özellikle kadınların bilinçlenmesinde bir süreç başlatmıştır. Ayrıca yazarlar dergide, kadınların itaat ve toplumdan yalıtılmış durumunun erkeklere de zarar veren bir tutum olduğunu sürekli olarak ele almışlardır (Roberts, 2010, s.310). Kadınların ötekileştirilmeden toplumlarda yer bulabilmesi adına yazılı basın bazı ülkelerde destek vermeye çalışmıştır.

Ötekileştirmenin aile yapısı içinde geliştiğini düşünenler, özellikle evrensel insan hakları kavramlarının toplumlarla tanıştırıldığı bir süreçte düşünürlerin bunları erkek özelinde ortaya koyduklarını belirtmektedirler. Örneğin Rousseau, kadın için "yeni annelikten" eve kapatılmış ve çocuğundan tamamen sorumlu olan ve bu sorumluluğu farklı kamusal alan bilgilerinden beslenerek yerine getirmesi gereken ama aynı zamanda özel alanında da haddini bilmesi gereken bir kişi olarak bahsetmiştir (Vural, 2013, s.184). Toplumun ilerlemesi için çalışmalar yapan bir düşünürün eril söylemi dikkat çekicidir. Yine Rousseau, “...yurttaşlar oy vermelidir. Çünkü kişinin kararını dürüst bir halk önünde doğrulatma gereği siyasal bir erdemdir. Oy vermek özel değil, kamusal bir haktır. Gizli oy sadece rüşvetçiliği özendirmemek için gereklidir" der ve "Eşitsizlik Üzerine Söylev" eserinde siyasal, sosyal konularda eşitlik üzerinde durur. Rousseau, söylemlerinde sürekli eşitlik vurgusu yapmasına rağmen bu eşitliğin erkekler arasındaki bir anlayış olarak nasıl geliştirilebileceğini satır aralarına serpiştirmiştir (Üste, 2015, s.114).

Kadınlar, özel alan ile sınırlı kalmak istemediklerini sosyal alana çıkarak eğitim, siyaset, kültür, ekonomi, sanatgibi alanlarda olmaları gerektiğini ortaya koymak için "kadın hareketleri”"ni başlatmışlardır. 18. ve 19. yüzyılda sufrajetler (kadınlara genel oy hakkı elde etmek için başlayan bir kadın hareketi) sadece Amerika'da ve Avrupa'da değil, Asya ve Latin Amerika'daki kadınların siyasal hak arayışında etkinlik göstermiştir. Kadınların sosyal alana çıkmasının toplumsal denge açısından gerekliliğini anlatan kadınlar, siyasal hakların sosyal alana çıkmadan olamayacağını anlatmaya çalışmışlardır. Kadınların oy hakkı için verdikleri mücadelenin özellikle 1890-1920 yılları arasında süfrajet hareketinin yayılması ile karar mekanizmalarında kadınların olmasının toplumsal bir ihtiyaç olduğu üzerine sürekliçalışmalar başlamıştır (Dubos, 1998, s.252-253).

Kadın hareketlerinin etkisi süreklilik kazanmış ve 1917 yılında yapılan bir konferansta kadınlar konu olarak "Başkan, Kadınların Oy Hakkı Özgürlüğünü Kazanmaları Nasıl Olacak?” başlığını tartışmışlardır. Sufrajet hareketinin 
bu konuda yardımcı olacağının altı çizilirken, Paul, “...zihinlerdeki tutukluluğun kadınlar açısından kaldırılması gerekir..." sözleri ile kurulan kadın partisinin kadının kadına destek olması kadar erkeklerin de kendilerine verecekleri desteğin değeri üzerinde durmuştur. Basın bu konuda kendilerine destek vermiş ve "New York Tribune" adlı yayın yazarları sufrajet hareketinin ve kadınların oy hakkı istemelerinin haklı nedenlerini yazıları yoluyla paylaşmışlardır. Oy hakkının kazanımının kadınlar için bir devrim niteliğinde olacağını da vurgulamışlardır (Cott, 1987, s.59-61). Kadın hareketlerinin çabası her alanda olduğu gibi siyasal haklarda da ötekileştirilmeden toplumdaki yerlerini alması gereken kadınlara destek vermek olarak açıklanmıştır.

Ötekileştirme kavramının açıklanmasında günümüz düşünürlerinden Foucault, toplumun doğallığı kavramını açıklarken, kadın-erkek insanların ortaçağ sonlarından başlayarak birarada yaşamak, çalışmak ve üretmek durumunda olduklarını burada kadın-erkek diye bir ayırımın ya da ötekileştirmenin olmaması gerektiğini anlamalarına rağmen uygulamaya geçirmedikleri üzerinde durmaktadır. Toplumsal olarak varolan, o sırada tam olarak adı konulmayan ancak kadının dışlanmasının olumsuz yansımalarını gören düşünürlerin varlığından söz etmekte ve toplumsal doğallığın ötekileştirmeye karşı duracağını söylemektedir (Foucault, 2013, s.304-305). 18. ve 19. yüzyılda yaşanılan kadının ötekileştirilmesi sorunsalının 20. yüzyıl gerçeğinde de aşılamadığı üzerinde durmaktadır.

21. yüzyıla gelindiğinde halen kadınların ötekileştirildiği toplumların bulunduğu ve bu toplumlarda birçok alanda kadınların haklarını tam olarak kullanamadıkları gözlemlenmektedir. Örneğin, Afganistan'lı Malala bunlardan biridir ve verdiği mücadele ile Nobel barış ödülüne layık görülmüştür. Milyonlarca kadına örnek olabilmek için, eğitim hakkı başta olmak üzere diğer tüm hakların savunulmasında bir genç kadının mücadele gücünü göstermiştir. Kadınların edinmesi gereken önemli değerlerden birinin cesaret olduğunun altını çizmiştir. Oy hakkının bir kadın için ne denli önemli olduğunu sadece seçilebilmek değil aynı zamanda seçilmek adına anlatmaya çalışmıştır. Kadınlara oy hakkının verilmesi için mücadele eden kadın-erkek herkesin toplumların gelişimi için önemli bir rol model olduklarını belirtmiştir. Her kadının oy hakkının kullanılmasında ve gelişiminde bir misyonu olduğunu işaret etmiştir (Yousafzai, 2015, s.327).

Feminist düşünce ve bu düşünceyi uygulamaya çal1şanlar oy hakkı ve getirisindeki siyasal hakların önemine vurgu yapmaktadırlar. Örneğin, Feminist yazarlardan biri olan Butler de, insanı inşa eden koşuların belirlenmesi gerektiğini söylemekte ve insana atfedilen birtakım doğal anlaşılabilirlik normları olduğunu düşünmektedir. Ona göre doğal ve verili olduğu iddia edilen cinsiyetin kendisi de bir normdur. Butler'a göre, yüzyıllar boyunca sosyal pratikler içinde kimi zaman örtük kimi zaman açık bir biçimde işleyen normlar özneleri düzenlemeye ve normalleştirmeye hizmet etmiştir (Saliya, 2017, s.123). Butler, yasal düzenlemelerin özellikle siyasal kararların erkekler tarafından alınmasının, kadının temsilde de öteki kabul edildiğini anlatmaktadır. Ayrıca, temsil hakkı için mücadele eden kadınların aslında toplum içinde öteki olmadıklarını ispat etmeye çalıştığını da belirtmektedir.

\section{KADIN KATEGORISII VE TEMSIL SORUNU}

Kadınlar, modernleşme ile birlikte toplum içinde kendilerine yer aramaya başlamışlardır. Eğitim almaları gerektiğini yönetimlere duyurabilmek için çaba gösterirken aynı zamanda karar mekanizmalarında neden yer almadıklarını sorgulamaya başlamışlardır. Karar mekanizmalarında yer alan kadınların ihtiyaç duyulan kanunların çıkarılmasında etkin olabileceğini kadın hareketleri ile kıta Avrupası başta olmak üzere çeşitli ülkelerde ele almaya çalışmışlardır. Kadın hareketleri belirli ülkelerde siyasal haklar konusunda yol almalarını sağlayabilmiştir. Örneğin, 18. yüzyılda Londra'lı erkekler biraraya gelip sosyalleşmek için kahvehaneler ve kulüpleri oluştururken, Fransız kadınları ise sosyalleşme adına, Fransızların icadı olan kadınların oturma odasında arkadaşları ve dostlarıyla buluşup entelektüel sohbetler yapmışlardır. Aynı yüzyılda Fransa'da kadınlar yeni bir yaşam tarzı için uğraş vermişlerdir. Aile ile sınırlı bir yaşam olsa da birey olmanın önemi üzerinde durmuşlardır (Roberts, 2010, s.311).

Kadınların temsil sorununu aşmak için uğraştıkları ülkelerden biri de İngiltere'dir. İngiliz Devrimi, birçok açıdan yenilik sağlarken kadın ve kadın hakları konusunda istenilen gelişmeyi ortaya koyamamıştır. İngiltere'de bir restorasyon döneminin başlamasını merkezle taşra arasındaki ilişkilerin yeniden şekillenmesine neden olmuştur (Roberts, 1996, s.346). Kadın hakları ile ilgili açmazların olduğu ülke sadece İngiltere değil, tüm Avrupa olarak karşımıza çıkmaktadır.

Aydınlanma çağı ile Montesquieu, sosyal hayatın kanunlarla düzenlenmesi gerektiğini, kanunların yapıldığı ülkelere özgü olmasını ve kişilerin özgürlüğüne kavuşmasında yasaların yardımcı olması gerektiğini anlatırken erkek özelinden hareket etmiş ve kadınlara ilişkin yorum yapmamıştır. Voltaire, kişi özgürlüğünü savunurken kişiyi erkek olarak nitelendirmiştir. Hume, modern yaşama dair öğretileri ortaya koyarken bunları belirleyen ve uygulayanları erkekler olarak anlatmıştır. Kant, aklı kullanarak siyasal olaylara 
yön verilmesini istemiş ve insan aklını överken bunu erkekler üzerinden değerlendirmiştir (Kona, 2005, s.65-67).

Avrupa'da kadınların siyasal hakları için başlayan çalışmalar, Amerika'da kadın partisinin kurulması ile süreklilik göstermiştir. Sufrajet hareketine bağlı olarak Amerika'da 1913 yılında "Ulusal Kadın Partisi”" sadece ülkede değil aynı zamanda birçok ülkede ses getirmiştir. Alice Paul ve Lucy Burns, bu partinin kuruluşunda ve işleyişinde öncü kadınlar olarak yer almışlardır. Birinci dalga feminizm çerçevesinde programlarını oluşturan parti oy hakkı ile ilgili çalışmalara hız vermiştir. Paul ve Burns "Ulusal Amerikan Sufrajet Kadınlar Birliği'nin” kadınların oy hakkı için 1905'den itibaren çeşitli çalışmaları yaptığını ve kadınların toplumsal sorunlarının çözümünde seçme ve seçilme hakkının öneminin biran önce kadın-erkek herkes tarafindan benimsenmesi gerektiğini ele almışlardır. Elizabeth Cady ve Susan Anthony politik söyleşiler için mitingler düzenlemiş ve halkın katıl1mını sağlayabilmişlerdir. Kadınların oy hakkı için mücadelesinde strateji belirlemek için sadece kadınların desteğinin yeterli olmadığını, erkeklerin de toplum içinde kendilerine destek vermeleri gerektiğini vurgulamışlardır (Cott, 1987, s.53-54).

1893 y1lında Yeni Zelanda da kadınlara oy hakkı verilmesi, diğer ülkelerde de kadınların oy hakkı için mücadelelerinde örnek teşkil etmiştir. 1920 yılı öncesinde sufrajet hareketinin ülkelerde dalga dalga yayılması ile kadınların seçme ve seçilme hakkı konusunda çalışmalarının yoğunlaşmasını beraberinde getirmiştir. Demokrasinin gelişimi ve demokratik bir ortamın olabilmesi için kadınların oy hakkının kazanmalarının önemi ve kadınların karar mekanizmalarında rol almalarının sadece kadınlar için değil, aynı zamanda ülkelerin kalkınması ve gelişiminde ne denli olumlu etkiler yapacağı ele alınmaya çalışılmıştır. Özelikle Aydınlanma felsefesi ile hız kazanan kadınların genel oy hakkı, 20. yüzyılda erkeklerin de tartıştığı konular arasına girmiştir. Kadınların hazırladıkları kampanyalara erkekler de destek vererek kıta Avrupası başta olmak üzere çeşitli ülkelerde 20. yüzyıl başında sufrajet hareketinin devamlılı̆̆ını sağlamaya çalışmışlardır. Bu konuya bir kadın problemi olarak bakılmaması gerektiğini ideolojilerle bir bağlantısı olmadığını kadınların haklarının başında siyasal haklar ve buna bağlı olarak seçme ve seçilme hakkının erkekler kadar onlara da verilmesi gerektiği üzerinde durmuşlardır (Aulette ve Wittner, 2012, s.361-363).

Kadın ve toplumdaki yeri konusu ele alındığında, buradaki konuların politikadan ve ülkelerin kadına bakış açısından bağımsız olarak değerlendirilmesi kadın haklarınınyanlış bir platformda tartışılmasını karşımıza getirebilecektir. Kadın haklarının gelişiminde siyaset ve ekonomi iki temel unsur olarak yer almaktadır. Kadın haklarının özellikle insan hakları olan evrensel kavramlarla bağdaştırılarak gelişiminin sağlanabilmesi için kadınların toplum içindeki yerinin güçlendirilmesi gerekmektedir. 20. yüzyılda kadın haklarının gelişimi ile ilgili yayınlanan "Hakların Gelişimi Deklerasyonu"nda “....her insan ve tüm insanlar için politik, ekonomik ve kültürel gelişim bir hak ve özgürlüktür... bunun korunmas1 gerekir" (Peters ve Wolper, 1995, s.301-302) ifadesi yer almıştır. Bunların korunabilmesi için seçim, seçimde kadın, kadınların oy haklarının önemi ve karar mekanizmalarında kadınların yer almasının haklar bakımından bir güvence olabileceğinin altı çizilmiştir.

Amerikan feminizm tarihinde bir başka önemsenen durum siyahi kadınların siyasal haklarını elde etmek için verdikleri mücadelelerdir. Amerikan tarihinde Ulusal Siyahi Feminist Kadınlar Organizasyonu (National Black Feminist Organization (NBFO)) 20. yüzyılda aktif bir biçimde siyahi kadınların sosyo-kültürel ve politik alanda ilerlemeleri için çaba göstermiştir. Politik haklar bakımından kadınlar arasında da farklılığı getiren bu durum zenginliğin dağılımında da adaletsizliği ortaya çıkarmıştır. Nixon, “...1968 seçimleri sonrasında gelişme adına stratejilerin herkes için ve herkese eşit olacağını açıklaması, ABD' de kadınlar arasında da eşitliğin olması gerekliliğini vurgulaması..."sadece erkek-kadın arasında eşitsizliğideğil, kadınlar arasında da 20. yüzyılda eşitsizliklerin boyutunu gözler önüne sermektedir (Harris, 2011, s.1-4).

20. yüzyılda devamlılık gösteren kadına dair eşitsizlikler özellikle, 17. yüzyıl İngiltere'sinde kadınlar tarafından "insan soyutlaması dışında bırakıldık" ifadesi ile sorgulanmıştır. Kadınlar için sadece İngiltere'de değil, Fransa, Belçika, Almanya gibi birçok ülkede hak mücadeleleri eşitsizliklerin giderilmesi adına başlamıştır. Marry Wollstonecraft yazılarının büyük bölümünde "kadınlık toplumsal bir kurgudur" (Çakır, 2013, s.422) teması içinde eşitsizlik sorunsalını işlemiştir. Kadınlar bu çalışmalar sonucunda eğitim ve iş alanında bazı hakları kazanmışlardır. Kadınlar erken dönemde Chartist Harekete de (1838-1848) katılmışlardır. Ancak, kadın hareketleri sonucunda eğitim ve iş alanında mesafe alabilen kadınlar siyasal hakları bakımından mahrum bırakılmışlardır. Dönemin ileri gelen düşünürleri hangi dünya görüşüne sahip olursa olsunlar özellikle kadınların oy kullanma hakları ile ilgili olumsuz açıklamalarına devam etmişlerdir. Siyasal haklar konusunda kadınlar adına diğer düşünürlerden farklı görüşleri olan: John Stuart Mill'dir. 


\section{KADINLARIN SEÇME VE SEÇILME HAKKI İÇIN MÜCADELEDE BIR ERKEK: JOHN STUART MILLL}

19. yüzyıl klasik liberalizmi ile 20. yüzyıl sosyal refah liberalizmi (müdahaleci liberalizm) arasında köprü kuran düşünür, liberalizmi geniş bir biçimde tanımlamıştır (18061873). "Özgürlük Üzerine ve Temsili Hükümetler Üzerine Düşünceler" adlı eserlerinde ana tema olarak “...görüşler susturulmamalı yoksa yanlışı doğruyla değiştirme firsatını kaybederiz... adına layık biricik özgürlüğün, başkalarının özgürlüğünü kısıtlamaya kalkışmamak, ya da onlarınözgürlüğüne kavuşma çabalarını engellememek kaydıyla, kendi iyimizi kendi bildiğimiz biçimde gerçekleştirmek" (Berktay, 2013, s.77-78) ifadesi ile özgürlük kavramının sadece erkekler için geçerli olamayacağının da temellerini atmışırır.

Liberalizm, "bireyin ve onun özgürlüğünün korunmasinı toplumsal adaletin temeli olarak kabul eden entelektüel ve ahlaki bir akım" (Çağla, 2017, s.220) olarak kabul edilir. Mill için özerklik temelli bir liberal anlayışta "bireysel özgürlük" tamamlayıcı bir değerdir. Mill aynı zamanda dünya görüşünü "eşit ilgi ve saygıyla" anlatmaya çalışmıştır. Bu anlatı, liberal paradigmanın (Erdoğan, 2005, s.25-27) oluşumunda ve gelişiminde de etkili olmuştur. Liberal paradigmanın oluşumunda hakkaniyet ve adalet ilkelerinden de bahsederek kurgulamasını bu değerler üzerinden yapmıştır.

Mill'in çağdaşlarından çok önemli bir farkı ise, "Kadınlara oy hakkını savunmasıdır". Cinsiyetler arasındaki farkın, sınıflar arasındaki fark gibi doğal değil, toplumun ve eğitimin yarattığı bir eşitsizlik olduğuna inandığ 1 ve kadın-erkek bütün insanların yeteneklerini ve zihinsel kapasitelerini tam olarak geliştirme hakkına sahip olduklarını savundukları için, kadınlara oy hakkı da dahil olmak üzere her türlü eşitlik sağlanmasının erken ve o dönem için tek erkek savunucusu olmuştur (Berktay, 2013, s.79).

Mill'in Harriet Taylor ile tanışması ve evlilikleri, düşünürü kadın hakları konusunda farklı yönelimlere ve anlayışlara götürmüştür. Mill'in bu düşünceleri şu şekilde özetlenebilir: Evlilik açık bir biçimde haklar ortaya çıkarır. Evlilikte eşler yerine getirilemeyen yükümlülükleri ve hakları sözleşmelerle elde edebilirler. 1861 yılında yazıp, 1869 yılında yayımladığı "Kadının İfadesi (The Subjection Of Women)" eserinde kadınların çeşitli alanlardaki sorunlarını doğrudan ele almıştır. Mill, bu arada kadınların uzun yıllardır mücadele ettikleri oy hakk1 için Westminister'da parlamento üyesi olarak yasa tasarısı sunmuştur (Üste, 2015, s.116).

Harriet Taylor Mill, her insanın kendi topraklarında aynı haklara sahip olmasının yanında, kadınların oy hakkına sahip olduğu bir devlet yapılanmasının gerekliliğini işaret etmiştir. Sivil ve siyasal haklar için, hiçbir cinsiyet ayrımı olmadan devletlerin anayasalarında yer almasının toplumsal cinsiyet açısından önemini vurgulamıştır. İngiltere başta olmak üzere evli insanları etkileyen mülkiyet hakkının her birey gibi kadına da hak haline getirilmesinin devletlerin sorumluluğu olarak görmüştür. Kadınlarla erkeklerin toplumda birlikte hareket etmeleri gerektiğini oy hakkının eşit bir biçimde sağlanmasının bir başlangıç olabileceğinin altını çizmiştir. Harriet Taylor Mill ile John Stuart Mill, 19. yüzyıl ortalarında kadın-erkek dayanışmasının (Üste, 2015, s.117) güzel ve anlamlı bir örneğini sergilemişlerdir.

Mill, İngiliz hukuk sisteminde kadının yeri konusunda muhalefet etmiş ve kadınların hukuki durumlarının revize edilmesi için çalışmıştır. Karı koca eşitliğini savunmuş ve ailenin toplumun en güçlü parçası olduğunu yinelemiştir (Shipka, 2009, s.10). Kadınların çalışma yaşamında desteklenmeleri gerektiğini sık sık dile getirmiştir. Kadınların çalışma yaşamında olabilmesi için karar mekanizmalarında yer almalarının önemi üzerine çalışmalarda bulunmuştur. Karar mekanizmalarında bulunabilmeleri için oy haklarının olması gerektiğini ve toplumun bunu desteklemesinin güçlü bir toplumu doğuracağını iddia eder. Çalışma yaşamına katılan kadınların özgüvenlerinin yüksek olacağını ve kararmekanizmalarında bulunmalarının kadınlara da güç vereceğini savunur (Dublin, 1975, s.89).

Kadınların Bağımlılığı Üzerine ünlü makalesinde (1869) şöyle der: "Günümüzde iki cins arasında varolan toplumsal ilişkileri düzenleyen ilke-bir cinsin hukuken diğerinebağımlı olması-kendi içinde yanlıştır ve şimdi de insanlığın gelişmesi açısından en önemli engellerden biri haline gelmiştir... Bunun yerini, hiçbir tarafa ayrıcalık ya da yoksunluk tanımayan tam bir eşitliğin alması zorunludur" (Berktay, 2013, s.79-80). Tarihte kadın yönetici olarak imparatoriçe ve kraliçelerin listesinin büyük bir uzunluğa ulaştı̆̆ını söyleyen Mill, "Bu gerçek o kadar inkar kabul etmez ki, uzun zaman önce birisi "kadınlar daha iyi yönetici olurlar, çünkü kralların emrinde kadınlar, kraliçelerin emrinde erkekler yönetir" diyerek bu tezi çürütmeye çalıştı ve kabul edilen bu gerçeğe hakaret etti" ifadesinde kadınların yönetim içinde olduklarını anlatmaya çalışmıştır (Mill, 2016, s.76-77).

Kadınların İkinciliği adlı eserinde, kadınların kamusal alana girmesini engelleyen olumsuz söylemlerin toplumları geriye götüreceğini ve güvensiz bir ortamı hazırlayabileceğini anlatmaya çalışmıştır. İlk kez 1867 yılında Avam Kamarası'nda "adam" kavramı yerine "kişis" ifadesinin kullanılmasını önermiştir. Avam Kamarası'nda yaptığı konuşmada, "bir toplumun uygarlık düzeyini öğrenmek isterseniz o toplumdaki kadının durumuna bakınız" (Ergin, 2007, s.67) ifadesi ile kadınların toplumsal açıdan görünmez kılınmasının mümkün olmadığını imgelemiştir. 
Avrupa'da kadın hareketleri erkeklere verilen oy hakkının kadınlara da verilmesi üzerine yoğunlaşmıştır. Siyasal oy hakkı İngiltere'de işçi erkekler için kabul edilmiş ancak kadınlar oy hakkından mahrum kalmışlardır. Bu süreçte, 1867 yılında kadınların oy hakkını elde etmeleri için imza kampanyası başlatmaları ve John Stuart Mill'in kadınlara oy hakkının tanınması için "Avam Kamarası"na sunduğu yasa önerisi sadece İngiltere'de değil,Avrupa'da da ses getirmiştir (Çakır, 2013, s.423). Mill, kadınları bu konuda parlamentoda savunan ilk erkek parlamenter olarak tarihe geçmiştir. Bu süreç, Milicent Garret Fawcett'in kurduğu Kadın Oy Hakları Dernekleri Ulusal Federasyonu (National Union of Women's Suffrage Societies) (Çakır, 2013, s.424) tarafindan desteklenmiştir.

Mill, kadınların da her türlü girişimde erkeklerle eşitdüzeyde başarılı olabileceğini vurgularken, onların ev işi ile uğraşmayı sürdürmesi gerektiğini varsaymıştır. Ailede cinsiyete dayalı işbölümünün "rızayla ama hiçbir biçimde hukukla değil, genel geleneklerle" gerçekleştiğini söyler ve bunun "iki kişi arasında işbölümü olduğunu" ( Kymlicka, 2016, s.536) savunur. Ayrıca, "Bir erkeğin mesleğini seçmesi gibi bir kadının da evlenirken bir evin ve ailenin idaresine ilişkin bir seçim yaptığ 1 , bu amaç için yıllarca sürecek çabasının ilk adımını attığı, başka bir şeyi ve her uğraşı değil, ama bu seçimin gerektirdikleriyle tutarlı olmayanları reddeceği düşünülebilir”'( Kymlicka, 2016, s.537) der.

Mill, özgürlük, eşitlik, bireysellik ve rasyonellik ilkelerinin liberalizmin temel değerleri olduğuna vurgu yaparken bunların toplumdaki herkes için geçerli olmasının anlamlı olduğunu tartışmıştır. Kadın-erkek "birey" olmanın özgürlük için kilit rol oynadığını savunmuştur. Mill, "devletin uzun vadede değeri, onu oluşturan bireylerin değerine bağlıdır” görüşüne sahip olmuştur. Düşünür, "iyi amaçlar için bile olsa, itaatkar araçlar haline getirmek amaciyla bireyi cüceleştiren bir toplumsal düzen, küçük adımlarla büyük başarı elde edilemeyeceğini öğrenmek zorunda kalır" (Berktay, 2013, s.51) ifadesi ile kadınların siyasal alanda hak elde etmeleri için parlamentoda verdiği mücadele dışında, kadınların aile içinde eşitliğin sağlanmasının önemi üzerinde durmuştur. Kadınların ev işleri dışında sosyal alanda yapabilecekleri birçok yetenekleri olduğunu bunları eğitimle destekleyerek toplumsal firsatlardan erkekler kadar yararlanmaları gerektiğini vurgulamıştır. Mill, “....işlerde kadınların erkeklerle rekabet etmesinin engellenmesi bir zorbalık ve topluma zarardır... İşi kendilerinden daha iyi yapabilecek kadınlar tarafindan ezilecek erkeklerle doludur..." (Mill, 2016, s.71-73) söylemi ile toplumsal kalkınmada kadın yoksa ilerlemenin yetersizliğine dikkat çekmiştir.
Kadınların siyasal haklarını savunan düşünür, bunun sağlanması ile yerel yönetimler, yasal sistem ve kamu hizmetleri içinde yapılacak reform çalışmalarında kadınların da bulunmasının toplum yararına olabileceğini vurgulamıştır. Faydacılık kuramına dayanarak açıkladığı bu tezi, kadın-erkek toplumun reformunda ve rasyonel bir eğitim kurumunun tasarlanmasında insan doğası biliminin kullanılması ile insanların mutlululuk için örgütleneceğini de söylemiştir (Redhead, 2001, s.203).

Birçok alanda, özelikle çarpışan iki görüşten birine ya da ötekine dayanmaktan çok, ikisinin çatışmasından çıkan, arada bir yerde yatan toplumsal ya da siyasal inanç ve hakikat alanında tartışmalarını yürütmüştür. Kadınların oy hakkını şu sözlerle savunarak ifade etmiştir: "Seçmenler kadın ve erkek olarak en iyisini seçmek zorundadır. Tanıdığım en akıllı adam olduğu için oy veriyorsam, sonradan kendimi onun yol göstericisi yerine koymuş olmaz mıyım? Ben doktorun bana yazacağı ilaç konusunda ne kadar cüretli ve 1srarc1 olabiliyorsam, seçtiğim kişi ile aramdaki durum bundan öteye geçemeyecektir" (Monk, 2004, s.428). Avam Kamarası'nda kadınlarında oy hakkı ile ilgili savunma yaparken "siyasal çoğunlukta olsa halk istencinin olması gerektiğini biliyoruz... fakat doğrunun ölçütü, halkın istenci olmasa da halkın iyi bir ölçütü ve kendi amacımız zorlanmamalı, halka kendi iyiliği için kendi istencini sınırsız ve doğrudan uygulamasına bazı kısıtlamaların getirilmesini ikna yoluyla kabul ettirilmelidir... (Monk, 2004, s.429) ifadesinde halk olarak kadın-erkek herkesi kastettiğinin altını çizmektedir. Temsili yönetimden yana olduğunu, gizli oy uygulaması, orantılı temsil yönteminin kullanılması gerektiğini çoğunluğun gücü ifadesinde kadınların bu ifadenin dışında düşünülmemesi gerektiğini de belirtmiştir (Monk, 2004, s.473).

Mill, "Bir toplumun uygarlık düzeyini öğrenmek isterseniz o toplumdaki kadının durumuna bakınız" (Ergin, 2013, s.67) ifadesi ile parlamentoda oy hakkının kadınlar için öneminin toplumda nasıl bir olumlu etki yapabileceğinin altını da çizmiştir. Mill, o dönemde kadınların özellikle oy hakkı başta olmak üzere kadın-erkek eşitliği üzerine söyledikleri May'in 20. yüzyılın ikinci yarısında anlattığ1 "yaratma cesareti"dir (May, 2015, s.39). May bu kavramı "tarihin kör silindirinin önüne uzanıp, geleceğe daha insanca ve adil bir toplumun kalıbını dökme şansı" olarak anlatır. May, “Kendi farkındalıklarımı ile toplumu etkileyebilmek ve farkında$1 \mathrm{k}$, insanın kendisine ve dünyaya karşı duyarlı, bilinçli, uyanık olması, bir bilme çabasıdır" diye niteler (May, 2015, s.40). Mill'i kadın hakları konusunda diğer çağdaşlarından farklı kılan May’in nitelendirdiği, bu duyarlılığa, bilince ve uyanıklığa sahip olmasıdır. 


\section{SONUÇ}

20. yüzyılın etkili İngiliz düşünürlerinden olan John Stuart Mill, mevcut toplumsal ilişkileri düzenleyenkadın-erkek arasındaki durum ve tutumların eşitlik ilkesine göre oluşturulması gerektiğini söylem dışında, uygulamaya koyabilen iyi bir örnektir. Çağdaşı olan düşünürlerin hepsi eşitlik, özgürlük, hoşgörü ve uzlaşı gibi kavramların olması gerektiğini imgelerken bunları erkek özelinde ele almışlardır. Oysa Mill, kadın hareketleri ile ilgili çalışmalar yapan ve kadın hareketlerinin siyasal haklar için bir dinamik yarattığını kabul eden düşünür olarak karşımıza çıkmaktadır. Entelektüel yapının toplum içinde gelişebilmesi için "mükemmel bir eşitliğin" olması gerektiğini savunmuştur. Karar alma mekanizmalarında kadınların yer almasının olumlu yönlerini çeşitli eserlerinde topluma anlatmaya çalışmıştır.

Eşi Harriet Taylor Mill ile birlikte kadın-erkek birlikte hareket edildiğinde sorunların daha etkin, hızlı ve güvenilir bir biçimde nasıl aşılabildiğinin altını çizmiştir. O döneme kadar görülmesi zor bir kadın-erkek dayanışmasının parlamentoya kadar uzanan yolculuğunda siyasal haklar başta olmak üzere, kadınların da eğitim, kültür, sanat, sosyal hayat içinde neden olmaları gerektiğini kadınlar adına "Avam Kamarası"nda savunan tek erkektir. Eril bir söylemin geliştiği Avam Kamarası'nda hazırladı̆̆ 1 "kadınların oy verme hakkı" ile ilgili yasa tasarısını sunması, tarihte bir ilki de beraberinde getirmiştir.

Yüzyıllar boyunca tartışılan ayrımcılığın, ötekileştirmenin toplumlar için öncelikle insanların mutluluğunu engelleyeci bir özelliği olduğunu ortaya koymaya çalışmıştır. $\mathrm{Bu}$ anlatılar, kadın-erkek ilişkileri ve özellikle siyasal alanda kadınların yer bulmaları ile ilgili çarpıcı örneklerdir. Kadın-erkek her alanda birarada hareket etmenin toplumları ve insanlığı ne denli ileri götürebileceğini önyargılardan uzaklaşmış bir şekilde ele alan önemli bir düşünürdür. Toplumlarda, kadınların ötekileştirilmesinin yine toplumlar için büyük bir kayıp olduğunu yüzyıllar önce dile getirebilmiştir.

\section{KAYNAKÇA}

Ağaoğulları, M.A. (2012). Jean - Jacques Rousseau: halk kendini yaratıyor. M.A. Ağaoğulları (Ed.) Sokrates'ten Jakobenlere Batı'da Siyasal Düşünceler. İletişim Yayınları:İstanbul.

Alkan, T. (1993). Siyasal ahlak ve siyasal ahlaksızlık. Bilgi Yay1nevi:İstanbul.

Assoun, P.L. (2012). Franfurt okulu. (I. Ergüden Çev.) Dost Kitabevi:Ankara.

Aulette J.R. ve Wittner J. (2012). Gendered worlds. Oxford University Press: New York.
Berktay, F. (2013). Liberalizm. H. B. Örs (Ed.) 19.yüzyıldan 20. yüzyıla modern siyasal ideolojiler (ss.47-106). İstanbul Bilgi Üniversitesi Yayınları:İstanbul.

Braudel, F. (2001). Uygarlıkların grameri. (M.A.Kılıçbay Çev.) İmge Kitabevi:İstanbul.

Cott, N. F. (1987). The grounding of modern feminizm. Vail-Ballou Press: Binghamton, New York.

Çağla, C. (2017). Siyaset bilimi. Bilge Yayınları:İstanbul.

Çaha, Ö. (2010). Sivil kadın-Türkiye'de sivil toplum ve kadın. Savaş Yayınevi: Ankara.

Çakır, S. (2013). Feminizm. H.B. Örs (Ed.) 19.yüzyıldan 20. yüzylla modern siyasal ideolojiler (ss.413-467). İstanbul Bilgi Üniversitesi Yayınları:İstanbul.

Dubos, E.C. (1998). Woman suffrage and women's rights. New York University Press:New York and London.

Dublin, T. (1975). Women, work and protest in the early lowell Mill, Carfax Publishing: United Kingdom.

Erdoğan, M. (2005). Liberalizm ve Türkiye'deki serüveni. M. Y1lmaz (Ed.) Liberalizm. (ss.23-41). İletişim Yayınları:İstanbul.

Ergin, A.B. (2013). Toplumsal cinsiyet, kadın ve görünmezlik. M. Tekcan (Ed.) Kadın kitabı. Umuttepe Yayınları: Kocaeli.

Foucault, M. (2013). Güvenlik, toprak, nüfus. (F.Taylan Çev.)İstanbul Bilgi Üniversitesi Yayınları:İstanbul.

Gürses, D. (2005). Avrupa'nın karanlık yüzü. Doğu Batı Düşünce Dergisi. Sayl:30, (77-89).doi:1303-7242.

Habermas, J., Öteki olmak, ötekiyle yaşamak.(İ. Aka Çev.)Yap1 Kredi Yayınları:İstanbul.

Harris, D. (2011). Black feminist politics from Kennedy to Obama. Palgrave Macmillan: New York.

Kerber, Linda K. (1980). Women of the rebuplic. By The University Of North Carolina Press: Virginia.

Kona, G.G. (2005). Batı'da aydınlanma doğu'da batılılaşma. Okumuş Adam Yayınları:İstanbul.

Kulak, Ö. (2013). Thomas Hobbes. A. Tunçel ve K. Gülenç (Ed.) Siyaset felsefesi tarihi Platon'dan Zizek'e.Doğubatı Yayınlar1:Ankara.

Kymlicka, W. (2016). Çăgdaş siyaset felsefesine giriş. (E. Kılıç Çev.) İstanbul Bilgi Üniversitesi Yayınları:İstanbul.

May, R. (2015).Yaratma cesareti. (a. Oysal Çev.) Metis Yayınlar1:İstanbul.

Mill, J.S. (2016). Kadınların özgürleşmesi. (D.B. Aksel Çev.) Pinhan Politika Yayınları:İstanbul.

Monk, L.M. (2004). Modern siyasal düşünce tarihi. (N. Arat Çev.) Say Yayınları:İstanbul.

Peters, J. ve Wolper, A. (1995). Women's rights international feminist perspectives human rights. Roudledge: London.

Redhead, B. (2001). Siyasal düşüncenin temelleri. (H.Özdemir Çev.)Alfa Yayınevi:İstanbul.

Roberts, J.M. (2010). Avrupa tarihi. (F.Aytuna Çev.) İnkılap Yayınevi:İstanbul. 
Robinson, D ve Groves, j. (2012). Felsefe.(B.Taşyakan) NTV Yayınları:İstanbul.

Saliya, D.A. (2017). Judith Butler ve postmodern feminizm. (D.A. Saliya Çev.) Kibele Yayınları:İstanbul.

Shipka, T. (1986). John Stuart Mill on woman rights. PrometheusBoooks:London.

Soutou, G.H. (2014). Avrupa Birliği tarihi. (A. Alp Çev.) Bilge Kültür Sanat Yayınları:İstanbul.

Üste, R.B. (2015). Hegel - Rousseau, Mill ve Hayek'in değerlendirmelerinde toplumda ötekileştirilen "kadın"ın konumu.
Dokuz Eylül Üniversitesi Edebiyat Fakültesi Dergisi. Cilt:3, Sayl:4, (103-126).

Vural, E.E. (2013). Annelik, feminizm, tarih. Doğu Batı Düşünce Dergisi. Sayl:64,(181-203).doi:1303-7242.

Yousafzai, M. (2015).I am Malala. Back Bay Books / Little, Brown and Company: New York.

Zabc1, F. (2012). Spinoza ve Locke: siyasal özgürleşmeden bireysel özgürlüğe. M.A. Ağaoğulları (Ed.) Sokrates'ten Jakobenlere Batı'da Siyasal Düşünceler. İletişim Yayınları:İstanbul. 